\title{
RHINOLOGY
}

\section{The value of Nigella sativa in the treatment of experimentally induced rhinosinusitis}

\author{
Potenziale della Nigella sativa nel trattamento della rinosinusite indotta in setting \\ sperimentale \\ O. YORUK ${ }^{1}$, A. TATAR ${ }^{1}$, O.N. KELES ${ }^{2}$, A. CAKIR ${ }^{3}$ \\ ${ }^{1}$ Department of Otorhinolaryngology, Head and Neck Surgery, School of Medicine, Ataturk University, Erzurum, \\ Turkey; ${ }^{2}$ Department of Histology and Embryology, School of Medicine, Ataturk University, Erzurum, Turkey; \\ ${ }^{3}$ Department of Chemistry, Faculty of Science and Art, Kilis 7 Aralık University, Kilis, Turkey
}

\begin{abstract}
SUMMARY
The aim of this study was to investigate the effect of Nigella sativa and cephalexin in the therapy of experimental bacterial rhinosinusitis. Bacterial rhinosinusitis was induced with Staphylococcus aureus. Rabbits were divided into five groups; control $(\mathrm{n}=6), \mathrm{N}$. sativa $50 \mathrm{mg}$ / $\mathrm{kg} / \mathrm{d}(\mathrm{n}=6), N$. sativa $100 \mathrm{mg} / \mathrm{kg} / \mathrm{d}(\mathrm{n}=6)$, N. sativa $200 \mathrm{mg} / \mathrm{kg} / \mathrm{d}(\mathrm{n}=6)$, and cephalexin $20 \mathrm{mg} / \mathrm{kg} / \mathrm{d}(\mathrm{n}=6)$ groups. $N$. sativa was given orally for 7 days. The same volume of normal saline $(0.9 \% \mathrm{NaCl})$ was given as a vehicle to the control group for the same period. After treatment period, sinus mucosa samples were evaluated using stereological and histopathological methods. Half of the maxillary sinus mucosa samples were frozen at $-80^{\circ} \mathrm{C}$ for further analysis of NO levels. Pathology revealed a severe acute inflammatory process in rabbits treated with saline. Only mild inflammation was determined in cephalexin group, $N$. sativa $100 \mathrm{mg} / \mathrm{kg} / \mathrm{d}$ and $N$. sativa $200 \mathrm{mg} / \mathrm{kg} / \mathrm{d}$ groups. The level of NO increased in the saline group was significantly reduced in all treatment groups. N. sativa may prevent histopathological changes of rhinosinusitis via decreased NO levels in a dose dependent manner and can be used in the treatment of rhinosinusitis diseases.
\end{abstract}

KEY WORDS: Nigella sativa $\bullet$ Rhinosinusitis $・$ Nitric Oxide $・$ Neutrophil $\bullet$ Rabbit

\section{RIASSUNTO}

Obiettivo del presente studio è stato quello di investigare l'effetto della Nigella sativa e della cefalexina nel trattamento della rinosinusite batterica indotta in setting sperimentale. La rinosinusite batterica è stata indotta mediante stafilococco aureo. I conigli sono stati suddivisi in 5 gruppi; uno di controllo $(n=6)$, $N$. sativa $50 \mathrm{mg} / \mathrm{kg} / \mathrm{d}(\mathrm{n}=6)$, $N$. sativa $100 \mathrm{mg} / \mathrm{kg} / \mathrm{d}(\mathrm{n}=6)$, $N$. sativa $200 \mathrm{mg} / \mathrm{kg} / \mathrm{d}(n=6)$, e cefalexina $20 \mathrm{mg} / \mathrm{kg} / \mathrm{d}(\mathrm{n}=6)$. La N. sativa è stata somministrata per via orale per 7 giorni. Lo stesso volume di soluzione salina $(\% 0,9 \mathrm{NaCl}) \grave{e ̀ ~ s t a t o ~}$ quindi somministrato al gruppo di controllo per lo stesso periodo di tempo. Dopo il periodo di trattamento i campioni di mucosa dei seni mascellari sono stati valutati utilizzando metodologie istopatologiche e stereologiche. La metà dei campioni di mucosa del seno mascellare sono stati congelati a $-80^{\circ} \mathrm{C}$ per una successiva analisi dei livelli di ossido nitrico. L'analisi patologica ha rivelato un intenso processo infiammatorio in atto nei conigli trattati con sola soluzione salina. Solo un lieve grado di infiammazione è stato invece rilevato nei conigli nei gruppi trattati con cefalexina, $N$. sativa $100 \mathrm{mg} / \mathrm{kg} / \mathrm{d}$, e N. sativa $200 \mathrm{mg} / \mathrm{kg} / \mathrm{d}$. Il livello di ossido nitrico, elevato nel gruppo placebo, è risultato invece essere ridotto negli altri gruppi. La N. sativa potrebbe prevenire i ambiamenti istopatologici indotti dalla rinosinusite mediante una riduzione dei livelli di ossido nitrico con andamento dose dipendente, e potrebbe essere usata nel trattamento della rinosinusite.

PAROLE CHIAVE: Nigella sativa $\bullet$ Rinosinusite $\bullet$ Ossido nitrico $\bullet$ Neutrofili $\bullet$ Coniglio

Acta Otorhinolaryngol Ital 2017;37:32-37

\section{Introduction}

Rhinosinusitis is one of the most frequently reported chronic diseases. In contrast to acute rhinosinusitis, where bacterial or viral aetiology is well established, chronic rhinosinusitis has been defined as an inflammation of the mucous membrane of the paranasal sinuses resulting from impaired transport mechanisms ${ }^{1}$. Local and systemic host immune responses interact under such conditions, leading to bacterial and respiratory virus effects in the pathophysiological events which is characterised by hyperaemia, haemorrhage and submucosal oedema with polymorphonuclear infiltration of rhinosinusitis ${ }^{2}$. Therefore, treatment of rhinosinusitis must break the vicious cycle of inflammation, oedema formation and mucous hypersecretion, before antibiotic treatment. Although treatment of rhinosinusitis is usually based upon use of antibiotics and/ or surgery, it may result in both high medical costs and development of multiple drug resistance in sinusitis-causing pathogenic microorganisms in humans ${ }^{34}$. In this regard, new antimicrobial substances from various sources like medicinal plants are arousing interest. 
Nitric oxide (NO) is one of the most abundant free radicals in the body and acts as a signalling or toxic agent between cells. Excess NO production causes mitochondrial respiratory enzyme inhibition ${ }^{5}$. NO has been described in many cell types in a variety of tissues, where it acts as a regulator of vascular tone, neurotransmitters, acute and chronic inflammation and host defence mechanisms ${ }^{67}$. It is involved in innate immunity, which is generated during immune and inflammatory actions as a toxic agent towards infectious organisms ${ }^{89}$. Neutrophils are capable of sustained release of high levels of NO, initiated by inflammatory cytokines and bacterial products ${ }^{10}$. As a result, many types of infections may cause an increase in levels of NO.

Nigella sativa ( $N$. sativa), belonging to the Ranunculaceae family, is an annual herbaceous plant native to Asian and Mediterranean countries. The plant is known as "black cumin" or "black seed". There are numerous reports on the phytochemical, pharmacological and toxicological properties of black cumin ${ }^{11}{ }^{12}$. Recent studies have shown that $N$. sativa seeds possess various pharmacological effects including analgesic, antipyretic, anti-inflammatory and anti-nociceptive, antioxidant, anti-tumour and cytotoxic, anti-diabetic and anti-ulcer properties ${ }^{913-21}$. Many of these properties have been attributed to its quinone constituents, and especially the thymoquinone of black cumin seeds ${ }^{17}$. Many reports have also been cited the actions of $N$. sativa seed extracts or its oil on different bacterial isolates ${ }^{11}$. The oil or its extracts have been found to have a broad spectrum of antibacterial activity ${ }^{13}$. It has also been demonstrated that both crude alkaloid extracts and water extracts of $N$. sativa seeds were effective against a variety of organisms, isolated from human patients suffering from septic arthritis, and even many organisms that were resistant to antibiotics ${ }^{22}$.

The aim of this study was to document the effects of three different doses of oral administration of Nigella sativa in a well-characterised rabbit model of rhinosinusitis, compared with cephalexin treatment, by analysing the number of neutrophils, histopathology and level of NO of the nasal mucosa following treatment.

\section{Materials and methods}

\section{Animals}

Thirty adult male albino rabbits weighing an average of 3 $\mathrm{kg}$ were obtained from Ataturk University Experimental Animal Laboratory of Medicinal and Experimental Application and Research Centre. The rabbits were maintained in our laboratory under controlled environmental conditions and fed ad libitum consumption of pelleted feed mixture that was formulated to meet or exceed National Research Council recommendations (National Research Council, 1995). Animal experiments were performed in accordance with the national guidelines for the use and care of laboratory animals and were approved by the local animal care committee of Ataturk University.

\section{Drugs}

The seeds of $N$. sativa were purchased from a local market. $N$. sativa seed samples $(200 \mathrm{~g})$ were separately extracted four times with $600 \mathrm{ml}$ of chloroform $\left(\mathrm{CHCl}_{3}\right)$ or ethanol (EtOH) at room temperature. After the organic solvents were evaporated to dryness under vacuum at low temperature using a rotary evaporator, $59.6 \mathrm{~g}$ liquid $\mathrm{CHCl}_{3}$ extract (29.8\% yield) and $51.8 \mathrm{~g}$ liquid ethanol extract (51.8\% yield) were obtained.

\section{Experimentally induced rhinosinusitis and treatment}

The animals were inoculated with Staphylococcus aureus (S. aureus) after the right nasal cavity was packed with Merocel $^{\mathrm{R}}$ (Medtronic Xomed, Jacksonville, FL, USA). Twenty-four hours after bacterial inoculation, the Meroce $^{R}$ in the right nasal cavities was removed. Thirty animals were assigned randomly to receive saline (peroral, group 1), $50 \mathrm{mg} / \mathrm{kg} / \mathrm{d} \mathrm{N}$. sativa per-oral (group 2), $100 \mathrm{mg} / \mathrm{kg} / \mathrm{d}$ N. sativa per-oral (group 3); $200 \mathrm{mg} / \mathrm{kg} / \mathrm{d}$ $N$. sativa per-oral (group 4) and $50 \mathrm{mg} / \mathrm{kg} / \mathrm{d}$ cephalexin (i.m.) (group 5) daily for 7 days. Twenty-four hours after the treatment period, the animals were sacrificed with injection of sodium pentobarbital via the auricular vein and then decapitated after ensuring death.

Preparation of bacterial suspension and induction of rhinosinusitis

S. aureus strain ATCC 25923 was suspended at a concentration of $900 \times 10^{6}$ cells/mlusing a McFarland Nephelometer Standard III at the Department of Microbiology, School of Medicine, Ataturk University, Erzurum, Turkey. After administration of a sedative, the nasal cavities were packed with Meroce $^{\mathrm{R}}$ for indirect obstruction of the maxillary sinus ostium ${ }^{23}$. The nasal dorsum was aseptically prepared with povidone-iodine before administration of a local anaesthetic to the skin and adjacent soft tissue. Next, $0.5 \mathrm{ml}$ of bacterial suspension was injected to the right maxillary cavity using a hypodermic syringe.

\section{Histological and stereological procedures}

For analyses, dissected tissue samples were fixed in $10 \%$ formalin. After fixation, the tissue samples were decalcified with EDTA. The decalcified tissue samples were then washed, dehydrated in ascending graded alcohols, cleared in xylene, and embedded in paraffin. For stereological examination, 20 micron sections were taken from the blocked tissues using a systematically randomised sampling method ${ }^{2425}$. For histological examination, 5 micron sections were taken from tissue blocks. After deparaffinisation and rehydration, serial sections were stained with haematoxylin and eosin.

An unbiased stereological technique, the optical dissector/fractionator method, was used to estimate neutrophil 
numerical density the serial sections of the sinus mucosa 2627 . The neutrophils in 20 micron sections were counted using a system for image analysis consisting of a light microscope (Leica DM4000 B, Cambridge, UK), equipped with an X-Y-Z movement-sensitive stage (BioPrecision MAC 5000 controller system; Ludl Electronic Products, Hawthorne, NY, USA) and a video camera (Optronics MicroFire, Goleta, CA, USA) coupled to a computer containing Stereo Investigator software (MicroBrightField, Williston, VT, USA).

\section{Extraction of maxillary sinus mucosa and measurement of nitric oxide level}

Sinus mucosa tissue NO levels were measured using the Griess reagent as previously described ${ }^{2829}$. Griess reagent, a mixture (1:1) of $0.2 \% \mathrm{~N}$-(1-napthyl)ethylenediamine and $2 \%$ sulphanilamide in $5 \%$ phosphoric acid gives a red-violet diazo dye with nitrite, and the resultant colour was measured at $540 \mathrm{~nm}$. First, nitrate was converted to nitrite using nitrate reductase. The second step was the addition of Griess reagent, which converts nitrite to a deep purple azo compound; photometric measurement of the absorbance at $540 \mathrm{~nm}$ then determines the nitrite concentration. Protein interference was eliminated by treatment of the reacted samples with zinc sulphate and centrifugation for 5 min 10,000xg. Biochemical measurements were carried out using a Cecil CE 3041 (Cambridge, UK) spectrophotometer.

\section{Statistical analysis}

For all parameters studied, means and standard deviations were calculated. Statistical analysis was performed using SPSS 13 for Windows (SPSS Inc., Chicago, IL, USA). The analysis of variance with the post-hoc LSD (least significant difference) test was used to compare results for all the groups. A p $<0.05$ was considered statistically significant.

\section{Results}

\section{Physical examination}

There was nasal discharge in all animals at the time of the removal of Merocel. Macroscopically, there was also oedema at varying degrees in the right maxillary sinus of all animals when sinus cavities were opened after the treatment period.

\section{Histopathological lesions}

In our study, the numerical density of neutrophils was also estimated. For all groups (control, cephalexin, $N$. sativa $50 \mathrm{mg} / \mathrm{kg} / \mathrm{d}, N$. sativa $100 \mathrm{mg} / \mathrm{kg} / \mathrm{d}$ and $N$. sativa $200 \mathrm{mg} / \mathrm{kg} / \mathrm{d}$ ) the numerical density of neutrophils was $0.000351 / \mu \mathrm{m}^{3}, 0.000020 / \mu \mathrm{m}^{3}, 0.000072 / \mu \mathrm{m}^{3}, 0.000058 /$ $\mu \mathrm{m}^{3}, 0.000068 / \mu \mathrm{m}^{3}$ respectively (Table I and Fig. 1).

Severe neutrophil infiltration was detected in control rabbits treated with saline. Pathology revealed a severe acute inflammatory process, with neutrophil and oedema formation that permeated the maxillary sinus and surrounded a vasodilatation mucosal capillary. Several instances of vascular dilatation and haemorrhage were determined in section profiles.

Although the general architecture of the maxillary sinus in cephalexin groups was partly protected, no important pathological findings at the structural level were observed, but only mild inflammation (Fig. 2A). Neutrophil infiltration of the maxillary sinus was lower than in the saline group (Fig. 2A). Similar histopathological findings were observed in the $N$. sativa $100 \mathrm{mg} / \mathrm{kg} / \mathrm{d}$ and $N$. sativa $200 \mathrm{mg} / \mathrm{kg} / \mathrm{d}$ groups (Fig. 2C and 2D). In the $N$. sativa $50 \mathrm{mg} / \mathrm{kg} / \mathrm{d}$ group, neither maxillary sinus nor vascular

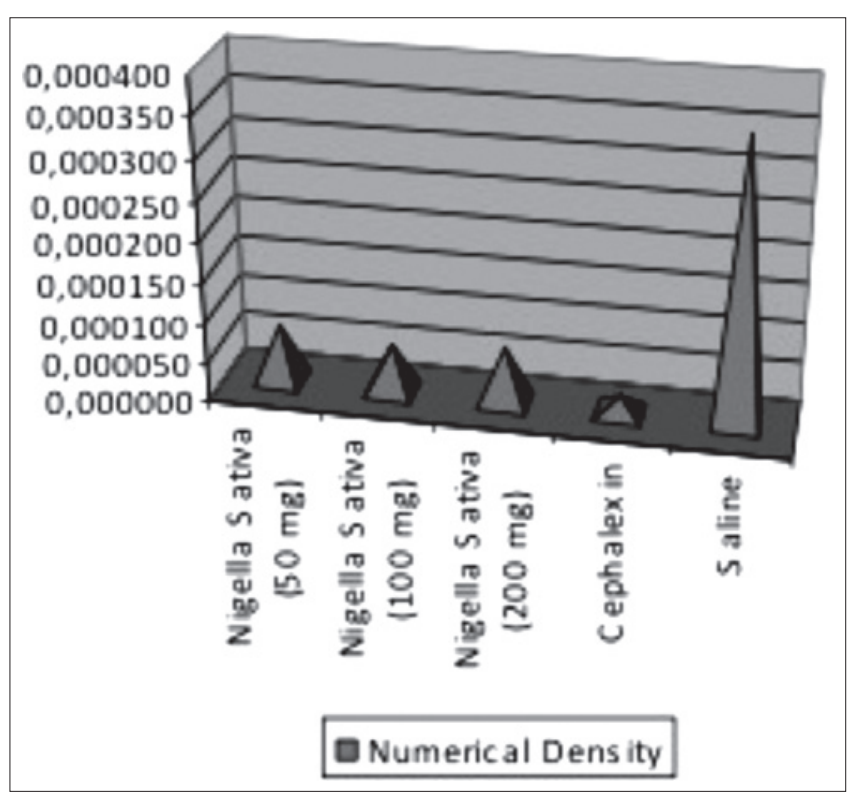

Fig. 1. Changes in mean neutrophil numerical density during treatment for 7 days in each group.

Table I. Neutrophil density in all the groups.

\begin{tabular}{lcccc} 
Groups & Numerical density of neutrophils $\left(\mathrm{n} / \mathrm{\mu m}^{3}\right)$ & Standard deviation & Standard error mean & $\mathbf{p}$ \\
N. sativa $(50 \mathrm{mg} / \mathrm{kg} / \mathrm{d}, \mathrm{N}=6)$ & 0.000072 & 0.00003950 & 0.00001613 & $<0.001$ \\
N. sativa $(100 \mathrm{mg} / \mathrm{kg} / \mathrm{d}, \mathrm{N}=6)$ & 0.000058 & 0.00004831 & 0.00002416 & $<0.001$ \\
N. sativa $(200 \mathrm{mg} / \mathrm{kg} / \mathrm{d}, \mathrm{N}=6)$ & 0.000068 & 0.00001058 & 0.00001067 & $<0.001$ \\
Cephalexin $(20 \mathrm{mg} / \mathrm{kg} / \mathrm{d}, \mathrm{N}=6)$ & 0.000020 & 0.00000496 & 0.00000202 & $<0.001$ \\
Saline $(\mathrm{N}=6)$ & 0.000351 & 0.00003726 & 0.00001862 & $<0.001$ \\
\hline
\end{tabular}




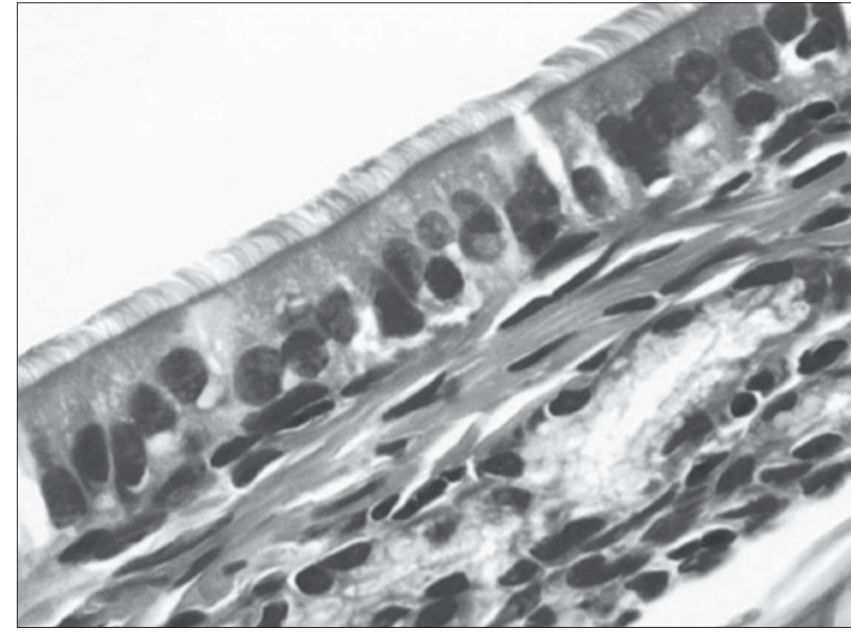

Fig. 2A. Histopathological section of rabbit maxillary sinus mucosa of treatment with cephalexin (H\&E X200).

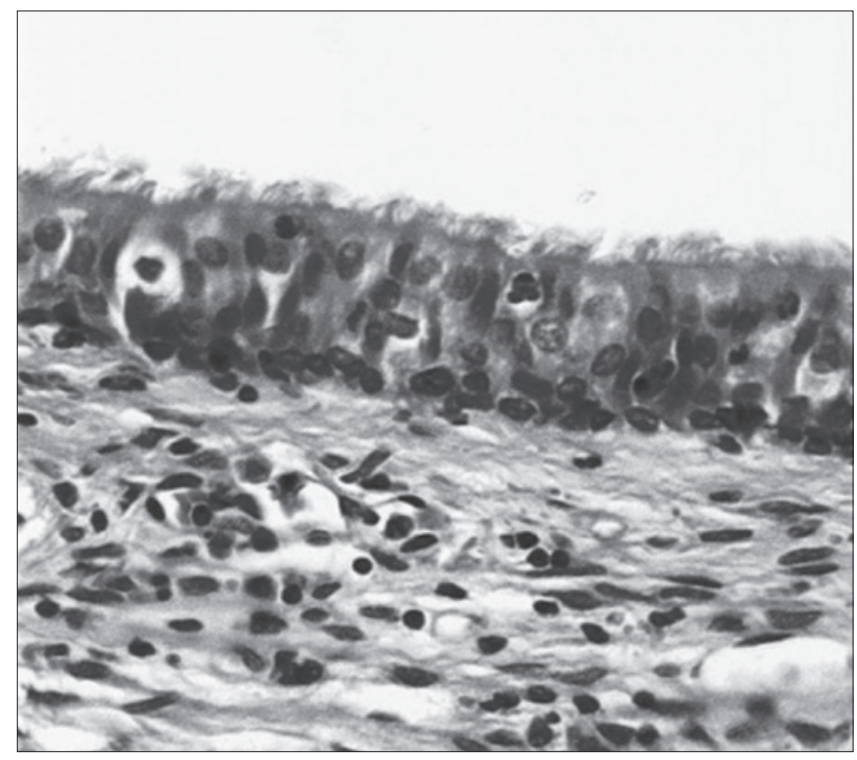

Fig. 2B. Histopathological section of rabbit maxillary sinus mucosa treated with N. sativa $50 \mathrm{mg} / \mathrm{kg} / \mathrm{d}$ (H\&E X100).

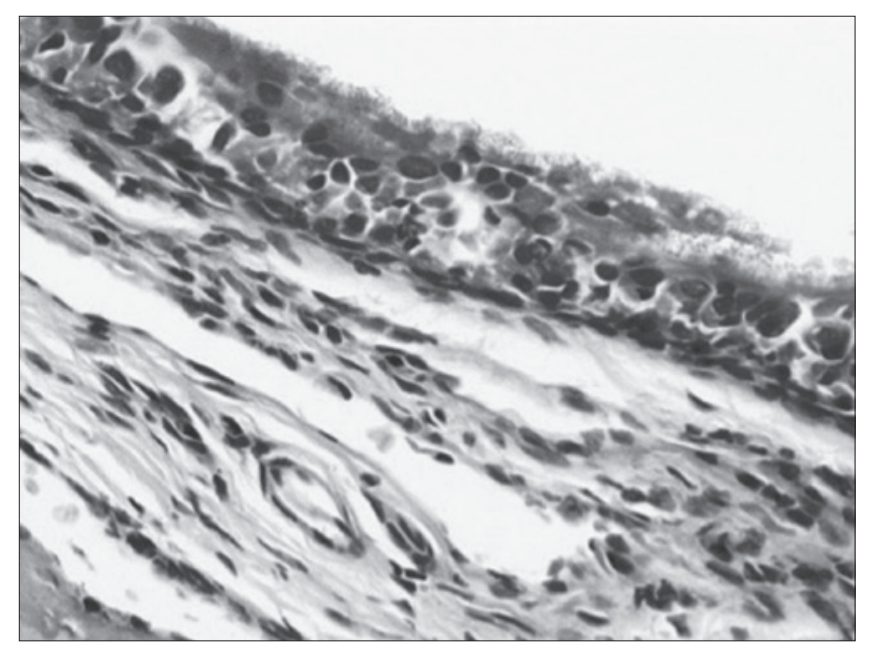

Fig. 2C. Histopathological section of rabbit maxillary sinus mucosa treated with N. sativa $100 \mathrm{mg} / \mathrm{kg} / \mathrm{d}$ (H\&E X100).

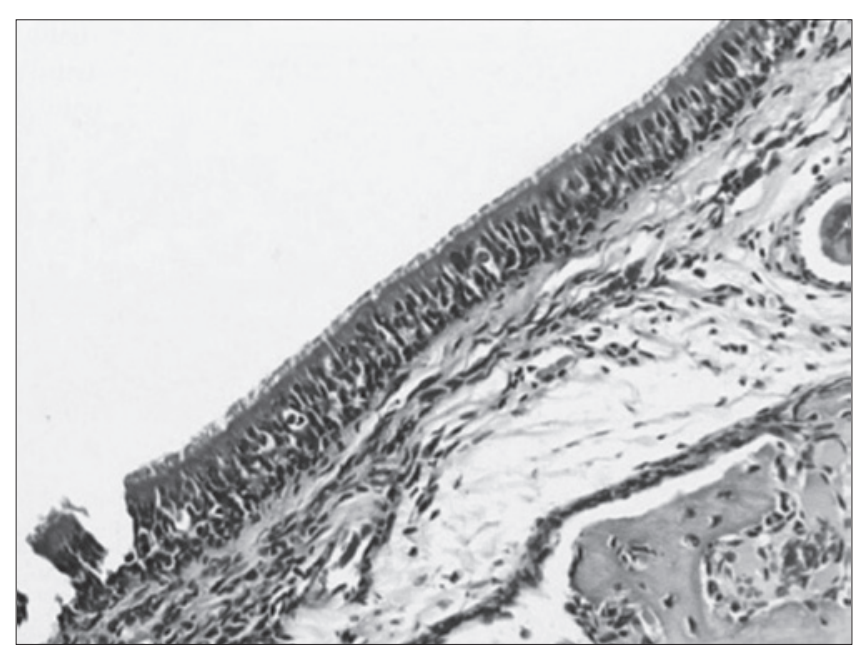

Fig. 2D. Histopathological section of rabbit maxillary sinus mucosa treated with N. sativa $200 \mathrm{mg} / \mathrm{kg} / \mathrm{d}$ (H\&E X50).

structures were normal in appearance compared with the cephalexin group (Fig. 2B).

\section{Nitric oxide level}

Table II shows that the level of NO increased in the saline treated group in comparison to the cephalexin $20 \mathrm{mg} / \mathrm{kg} / \mathrm{d}$, N. sativa $50 \mathrm{mg} / \mathrm{kg} / \mathrm{d}, N$. sativa $100 \mathrm{mg} / \mathrm{kg} / \mathrm{d}$ and $N$. sativa $200 \mathrm{mg} / \mathrm{kg} / \mathrm{d}$ groups. The mean tissue total NO levels were significantly $(p<0.001)$ higher in the saline group and correlated well with disease acuteness. Cephalexin $20 \mathrm{mg} / \mathrm{kg} / \mathrm{d}, N$. sativa $50 \mathrm{mg} / \mathrm{kg} / \mathrm{d}, N$. sativa $100 \mathrm{mg} / \mathrm{kg} / \mathrm{d}$ and $N$. sativa $200 \mathrm{mg} / \mathrm{kg} / \mathrm{d}$ had a similar effect on the levels of NO, all reducing its value, which were $163.31 \mu \mathrm{mol} /$ $\mathrm{ml}, 166.40 \mu \mathrm{mol} / \mathrm{ml}, 165.20 \mu \mathrm{mol} / \mathrm{ml}$ and $166.43 \mu \mathrm{mol} / \mathrm{ml}$ in experimental rhinosinusitis, respectively. In the saline control group, the value of NO level was $184.17 \mu \mathrm{mol} / \mathrm{ml}$.

\section{Discussion}

Nasal and paranasal sinus mucosa have a highly efficient system for the physiologic functions of olfaction, respiration, and protection ${ }^{30}$. The respiratory epithelial cell layer presents a physical barrier that prevents invasion by micro-

Table II. Effects of cefalexin and N. sativa on changes in the level of NO in sinus mucosa samples of rabbits in an experimental rhinosinusitis model. The groups treated with three different doses of N. sativa and cefalexin were compared with the saline group.

\begin{tabular}{lccc} 
Groups & $\begin{array}{c}\text { Number of } \\
\text { Animals }\end{array}$ & N0 $(\mu \mathrm{mol} / \mathrm{ml})$ & $\mathbf{p}$ \\
Control (Saline) & 6 & $184.17 \pm 3.09$ & - \\
Cefalexin $20 \mathrm{mg} / \mathrm{kg} / \mathrm{d}$ & 6 & $163.31 \pm 2.98$ & $<0.001$ \\
N. sativa $50 \mathrm{mg} / \mathrm{kg} / \mathrm{d} /$ & 6 & $166.40 \pm 0.22$ & $<0.001$ \\
N. sativa $100 \mathrm{mg} / \mathrm{kg} / \mathrm{d}$ & 6 & $165.20 \pm 0.43$ & $<0.001$ \\
N. sativa $200 \mathrm{mg} / \mathrm{kg} / \mathrm{d}$ & 6 & $166.43 \pm 0.43$ & $<0.001$ \\
\hline
\end{tabular}


organisms, and the mucociliary action prevents bacterial infection and protects the mucosa from injury and drying ${ }^{31}$. Sinusitis is one of the most frequently reported acute or chronic and heterogeneous diseases, which shows several types of aetiology. Where a bacterial or viral aetiology is well established, this has been defined as an inflammation of the mucous membrane of the paranasal sinuses resulting from impaired transport mechanisms ${ }^{1}$. Various systemic and local factors are known to be associated with nasal and sinus infections ${ }^{32} 33$. To maintain the physiologic condition of the nasal cavity and sinuses, it is known that nasal airflow, anatomical conditions, patency of the natural ostium, oxygen saturation in sinuses and mucociliary clearance all play important roles. When one of these physiologic conditions is changed, these abnormal conditions cause inflammatory reactions, due to an abnormal mucous membrane immunity, phagocytosis and bacteriologic action of the nasal secretion enzymes. The local and systemic host immune responses interact under such conditions, leading to bacterial and respiratory virus effects in the pathophysiological events, which are characterised by hyperaemia, haemorrhage and submucosal oedema with polymorphonuclear infiltration of rhinosinusitis ${ }^{32}$.

The aim of this study was to compare the effectiveness of three different doses of $N$. sativa, which was of natural herbal origin, with that of cephalexin. With this therapy, we aimed to ameliorate neutrophil numbers and inhibit the inflammation that was a consequence of the NO level in the sinuses. Cingi et al. reported no significant difference histopathologically, among an antibiotic treated group, a thymoquinone treated group and a negative control group in their experimental study in which they investigated the role of thymoquinone, a phytochemical component of $N$. sativa, for sinusitis therapy ${ }^{34}$. They proposed that thymoquinone can be a bioactive agent used for treatment of rhinosinusitis and have the same histopathological effect with an antibiotic. We obtained similar results herein.

The reduction of the neutrophil numbers was histopathologically relevant and statistically significant in both treatment groups, compared with the saline group. It similar in the group of rabbits treated with $N$. sativa $(100 \mathrm{mg} / \mathrm{kg} / \mathrm{d}$ and $200 \mathrm{mg} / \mathrm{kg} / \mathrm{d}$ ) and in the group treated with cephalexin. The results of our study have shown that rhinosinusitis with cephalexin eradicate infection and reduce inflammation. The effectiveness of $N$. sativa is based on its known mechanisms of action, which are anti-inflammatory, antioxidant and antimicrobial ${ }^{813} 15-17$.

NO may play a part in tissue damage, and its roles in the control of a variety of intracellular organisms have been described in some viral and fungal infections or protozoal infestations as a toxic agent towards infectious organisms ${ }^{35-38}$. However, the role of NO in bacterial infection has not been clearly defined; it may be cytostatic or cytotoxic, not only for invading microorganisms, but also for the cells that produce it and also for neighbouring cells.
For example, NO is a mediator of NK cell killing of target cells and regulates NK cell function; it inhibits activation of mast cells and can enhance or inhibit neutrophil activation, depending on its concentration ${ }^{39-41}$. Another potential mechanism includes a direct microbiocidal effect, via the reaction of $\mathrm{NO}$ with iron or thiol groups on proteins that inactivate enzymes systems in mitochondria. It may also interact with oxygen-derived radicals to generate molecules that may enhance its cytotoxicity. In addition, NO has been found to react with superoxide to form reactive oxidants capable of damaging target cells ${ }^{42}$.

Our results for tissue NO levels are in agreement with these data. Our results suggest that oxidative stress in tissue of rabbits with rhinosinusitis may cause an increase in NO, which arises because of tissue damage. $N$. sativa may be given to decrease the NO in patients with rhinosinusitis, with the hope of alleviating the observed toxicities. Since NO seems to have a dual role in bacterial rhinosinusitis, the high concentrations of NO could result in damage in sinus mucosa and $N$. sativa decreases the tissue level of NO via anti-inflammatory, microbiocidal or antioxidant functions.

\section{Conclusions}

Our findings underscore that acute bacterial rhinosinusitis can increase the level of NO and that high concentrations of NO may play an important role in the pathogenesis of rhinosinusitis of the impaired sinus tissue of rabbits. The results of our study suggest that $N$. sativa may prevent histopathological changes of rhinosinusitis via decreased NO levels in a dose dependent manner.

\section{References}

1 Hauptman G, Ryan MW. The effect of saline solutions on nasal patency and mucociliary clearance in rhinosinusitis patients. Otolaryngol Head Neck Surg 2007;37:815-21.

2 Epstein VA, Kern RC. Invasive fungal sinusitis and complications of rhinosinusitis. Otolaryngol Clin North Am 2008;1:497-524.

3 Biel M, Brovn CA, Levinson RM, et al. Evaluation of microbiology of chronic maxillary sinusitis. Ann Otol Rhinol laryngol 1998;7:942-5.

4 Otori N, Paydos G, Stierna P, et al. The antiinflammatory effect of Fusafungine during experimentally induced rhinosinusitis in the rabbit. Eur Arch Otorhinolaryngol 1998;55:95-201.

5 Sozmen EY, Kerry Z, Uysal F, et al. Antioxidant enzyme activities and total nitrite/nitrate levels in the collar model. Effect of nicardipine. Clin Chem Lab Med 2000;38:1-5.

6 Michel T, Feron O. Nitric oxide synthases: which, where, how, and why? J Clin Invest 1997;100:2146-52.

7 Maeda H, Akaike T. Nitric oxide and oxygen radicals in infection, inflammation, and cancer. Biochemistry (Moscow) 1998;63:854-65.

8 Bogdan C, Rollinghoff M, Diefenbach A. Reactive oxygen and reactive nitrogen intermediates in innate and specific immunity. Curr Opin Immunol 2000;12:64-76. 
9 Bogdan C, Rollinghoff M, Diefenbach A. The role of nitric oxide in innate immunity. Immunol Rev 2000;173:17-26.

10 Moncada S, Higgs A. The L-arginine-nitric oxide pathway. N Engl J Med 1993;329:2002-12.

11 Salem ML. Immunomodulatory and therapeutic properties of the Nigella sativa L. seed. Int Immunopharmacol 2005;5:1749-70.

12 Jalali HM, Zekavat B, Sereshti H. Use of gas chromatography-mass spectrometry combined with resolution methods to characterize the essential oil components of Iranian cumin and caraway. J Chromatogr A 2007;1143:215-26.

13 Singh G, Marimuthu P, de Heluani CS, et al. Chemical constituents and antimicrobial and antioxidant potentials of essential oil and acetone extract of Nigella sativa seeds. J Sci Food Agric 2005;85:2297-306.

14 Worthen DR, Ghosheh OA, Crooks PA. The in vitro anti-tumor activity of some crude and purified components of blackseed, Nigella sativa L. Anticancer Res 1998;18:1527-32.

15 Al-Ghamdi MS. The anti-inflammatory, analgesic and antipyretic activity of Nigella sativa. J Ethnopharmacol 2001;76:45-8.

16 Burits M, Bucar F. Antioxidant activity of Nigella sativa essential oil. Phytother Res 2000;14:323-8.

17 Hosseinzadeh H, Parvardeh S, Asl MN, et al. Effect of thymoquinone and Nigella sativa seeds oil on lipid peroxidation level during global cerebral ischemia-reperfusion injury in rat hippocampus. Phytomedicine 2007;14:621-7.

18 Badary OA. Thymoquinone attenuates ifosfamide-induced Fanconi syndrome in rats and enhances its antitumor activity in mice. J Ethnopharmacol 1999;67:135-42.

19 Swamy SMK, Tan BKH. Cytotoxic and immunopotentiating effects of ethanolic extract of Nigella sativa L. seeds. J Ethnopharmacol 2000;70:1-7.

20 Meral I, Yener Z, Kahraman T, et al. Effect of Nigella sativa on glucose concentration, lipid peroxidation, anti-oxidant defence system and liver damage in experimentally-induced diabetic rabbits. J Vet Med A Physiol Pathol Clin Med 2001;48:593-9.

21 El-Dakhakhny M, Barakat M, Abd El-Halim M, et al. Effects of Nigella sativa oil on gastric secretion and ethanol induced ulcer in rats. J Ethnopharmacol 2000;72:299-304.

22 Morsi NM. Antimicrobial effect of crude extracts of Nigella sativa on multiple antibiotics resistant bacteria. Acta Microbiol Pol 2000;49:63-74.

23 Johansson P, Kumlien J, Carlsöö B, et al. Experimental acute sinusitis in rabbits. A bacteriological and histological study. Acta Otolaryngol 1988;105:357-66.

${ }^{24}$ Gundersen HJ. Stereology of arbitrary particles. A review of unbiased number and size estimators and the presentation of some new ones, in memory of William R. Thompson. J Microsc 1986;143:3-45.

25 Gundersen HJ, Jensen EB. The efficiency of systematic sampling in stereology and its prediction. $\mathrm{J}$ Microsc 1987;147:229-63.
26 Gundersen HJ, Bagger P, Bendtsen TF. The new stereological tools: dissector, fractionator, nucleator and point sampled intercepts and their use in pathological research and diagnosis. APMIS 1988;96:857-81.

27 West MJ, Slomianka L, Gundersen HJ. Unbiased stereological estimation of the total number of neurons in the subdivisions of the rat hippocampus using the optical fractionator. Anat Rec 1991;231:482-97.

28 Moshage H, Kok B, Huizenga JR, et al. Nitrite and nitrate determinations in plasma: a critical evaluation. Clin Chem 1995;41:892-6.

29 Bories PN, Bories C. Nitrate determination in biological fluids by an enzymatic one step assay with nitrate reductase. Clin Chem 1995;41:904-7.

30 Baroody FM. Nasal and paranasal sinus anatomy and physiology. Clin Allergy Immunol 2007;19:1-21.

31 Sacco O, Silvestri M, Sabatini F, et al. Epithelial cells and fibroblasts: structural repair and remodelling in the airways. Pediatr Respir Rev 2004;5:35-40.

32 Epstein VA, Kern RC. Invasive fungal sinusitis and complications of rhinosinusitis. Otolaryngol Clin North Am 2008;41:497-524.

33 Kennedy DW. Pathogenesis of chronic rhinosinusitis. Ann Otol Rhinol Laryngol 2004(Suppl);193:6-9.

${ }^{34}$ Cingi C, Eskiizmir G, Burukoglu D, et al. The histopathological effect of thymoquinone on experimentally induced rhinosinusitis in rats. Am J Rhinol Allergy 2011;25:e268-72.

35 Piacenza L, Peluffo G, Radi R. L-arginine-dependent suppression of apoptosis in Trypanosoma cruzi: contribution of the nitric oxide and polyamine pathways. Proc Natl Acad Sci USA 2001;98:7301-6.

36 Saeftel M, Fleischer B, Hoerauf A. Stage-dependent role of nitric oxide in control of Trypanosoma cruzi infection. Infect Immun 2001;69:2252-9.

37 Lirk P, Hoffmann G, Rieder J. Inducible nitric oxide synthase-time for reappraisal. Curr Drug Targets Inflamm Allergy 2002;1:89-108.

38 Brunet RL. Nitric oxide in parasitic infections. Int immunopharmacol 2001;1:1457-67.

39 Cifone MG, Ulisse S, Santoni A. Natural killer cells and nitric oxide. Int Immunopharmacol 2001;1:1513-24.

40 Forsythe P, Gilchrist M, Kulka M, et al. Mast cells and nitric oxide: control of production, mechanisms of response. Int Immunopharmacol 2001;1:1525-41.

${ }^{41}$ Armstrong R. The physiological role and pharmacological potential of nitric oxide in neutrophil activation. Int Immunopharmacol 2001;1:1501-12.

42 Duhe RJ, Evans GA, Erwin RA, et al. Nitric oxide and thiol redox regulation of Janus kinase activity. Proc Natl Acad Sci USA 1998;95:126-31.

Address for correspondence: Arzu Tatar, Department of Otorhinolaryngology, Medical School, Ataturk University, 25240, Erzurum, Turkey. Tel. +90 442 2317130. Fax +90 442 2361301. E-mail: arzutatar@atauni.edu.tr 